\title{
5 The measurement of informal employment in Mexico
}

\author{
Rodrigo Negrete
}

Mexico has made the measurement of informal employment and employment in the informal sector a high priority for many years. The priority placed on informal employment is rooted in the country's economy, legal culture and demography. Mexico is a heterogeneous country, with a diverse economy. A vigorous manufacturing export sector (automobile, air and space industries) coexists alongside subsistence agriculture, street vendors, cottage industries and similar small-scale production. Moreover, in the formal manufacturing sector, the wave of globalisation in the 1990s created pressures to make intra-industry labour relationships as flexible as possible and in doing so promoted informal arrangements.

Mexico historically has had problems in implementing the rule of law. On the one hand, this means the state has a rather weak fiscal/tax base; on the other, vast numbers of the population do not have effective labour and social rights though these are enshrined in the Constitution. Further, many commercial transactions do not benefit from contractual guarantees.

Demographically, Mexico has a rapidly ageing population. Many have no pension and families are no longer large or live close enough to serve as a de facto social protection net. For these reasons, the standard indicators of employment and unemployment are not sufficient to serve as leading labour indicators or key signals to understand the changes in Mexico's labour market. Since 2012, Mexico's National Institute of Statistics and Geography (INEGI, in its Spanish acronym) has supplemented the standard economic indicators with data on informal employment and employment in the informal sector. As with the standard indicators, the indicators related to informal employment distinguish urban and rural areas and state-regional levels and are disseminated on a quarterly basis. This chapter describes the strategy adopted by Mexico to measure informality, provides statistical data on its informal economy and reports on the policy measures and reforms the data have triggered to improve the situation of the employed and the Mexican economy.

\section{The conceptual framework}

The 15th and the 17th International Conferences of Labour Statisticians (ICLS) set a classification framework which identifies the part of employment that is 
formal, the part that is informal and the modalities of the latter case to achieve a holistic classification of employment. ${ }^{1}$ The underlying logic of the framework is to apply operational criteria based on the status in employment classification:

- Independent (self-employed) workers are classified under an enterprisebased approach (informal sector).

- Dependent workers (either de jure or de facto) are classified based on their current employment relationship, i.e., whether it provides them (in law or in practice) basic or standard social benefit and social protection.

While not explicit in the 17th or the 19th ICLS recommendations, the concepts of the informal sector and informal employment broadly encompass those forms of labour market arrangements where risks are personal and not buffered by any institutional protection. Therefore, the concepts point to situations where their employment does not provide persons with the basic or standard guarantees relating to either their commercial transactions or employment relationships.

While informality is a diverse phenomenon, the final outcome or situation should not be confused with whatever causes it, for example, breaking the law, not knowing the law, blind spots in the law, ways to circumvent the law, new realities not yet covered in law, etc. Another essential point is that informality is a phenomenon or set of practices that in principle is widespread throughout the economy rather than in only a part of it.

\section{Mexico's measurement approach: the labour force survey}

The Mexico labour force survey (ENOE; Encuesta Nacional de Ocupación y Empleo) provides data for the country's key indicators on informal employment, comprising both the individual and the enterprise levels of data. ${ }^{2}$ The design of this survey has three key elements to produce these data:

- sample size of 120,000 dwellings (out of a total 30 million in the country);

- quarterly collection and reporting of data;

- special design (section 4) which includes questions on characteristics of the economic unit in which the respondent is working.

There are numerous strengths to this approach:

- Provides comprehensive data on informal employment and employment in the informal sector, by quarter.

- Yields statistical series for both short-term and structural analysis.

- Facilitates contrast with formal employment

- Provides the specific demographic context of the individual as well as the household. 


\section{Rodrigo Negrete}

- Supplies the labour matrix input needed by national accountants to calculate the size of the informal economy (share of gross domestic product, GDP) on an annual basis.

- Eliminates the need for additional costs in collecting and disseminating data available at the national level (including rural areas) as well as state (provincial) levels.

However, there are also weaknesses in the approach. It is easier to identify the size of informal employment than the size of one of its components, the informal sector. The measurement of the informal sector still remains challenging. In the case of proxy respondents, the person may not know or answer accurately questions on the characteristics of the economic unit. Moreover, the industry structure of the informal sector, in particular at certain levels of disaggregation (beyond the two-digit level) may not be accurate since the survey sample was not designed to take the industry classification into account.

\section{Statistics on the informal economy in Mexico}

Table 5.1 presents a comprehensive overview of employment in Mexico and is reported quarterly on the INEGI website (INEGI, n.d.). The employed population in Mexico is approximately 53.8 million workers with around 30.5 million (57 per cent) corresponding to informal employment and 23.3 million (43 per cent) to formal employment. Dependent wage/salary workers, comprising around 35 million of the employed, are the largest status category. Of these, around 15 million are informal and 20 million are formal (so for this subset, proportions are the other way round, 43 per cent informal and 57 per cent formal). The second largest category are own-account workers at around 12 million, most of whom (more than 10 million) are informally employed. Among the auxiliary non-paid workers, 97 per cent are contributing family workers and the remaining 3 per cent are non-family apprentices. ${ }^{3}$

Data are also provided on the sector composition of employment (Figure 5.1). Employment in (1) the informal sector is the largest component at 14.7 million, followed by (2) informal employment insertion in formal/registered economic units (7.5 million); (3) 5.9 million employed informally in agriculture; and (4) 2.2 million more in paid domestic service who are employed by private households. What in the following is called informality outside the informal sector encompasses these last three categories (2, 3 and 4).

One of the uses of the ENOE is to supply the national account system with the labour base required to achieve completeness and infer the contribution of the informal economy to GDP. Figure 5.2 shows the informal economy has contributed about one quarter of the total GDP of the country with a slight decrease from around 23.7 per cent of GDP in 2003 and a peak in 2009 as result of the global crisis to around 22.7 per cent in 2017. One of the unique features of the Mexico estimates is the calculation of not only the contribution made by the informal sector but also the contribution of informal employment outside the 
Table 5.1 Key data on informal labour, second quarter, 2018, national (total)

\begin{tabular}{|c|c|c|c|c|c|c|c|}
\hline \multirow[t]{4}{*}{ Indicator } & \multicolumn{7}{|l|}{ Estimations } \\
\hline & \multirow[t]{3}{*}{ Employed } & \multirow{3}{*}{$\begin{array}{l}\text { Formal } \\
\text { employment }\end{array}$} & \multicolumn{5}{|c|}{ Informal employment } \\
\hline & & & \multirow[t]{2}{*}{ Total } & \multirow{2}{*}{$\begin{array}{l}\text { Informal } \\
\text { sector }\end{array}$} & \multicolumn{3}{|c|}{ Outside the informal sector } \\
\hline & & & & & Subtotal & Non-farm & Farm \\
\hline 1. Employment by & 53785257 & 23317416 & 30467841 & 14745649 & 15722192 & 9781907 & 5940285 \\
\hline 1.1 Age groups & 53785257 & 23317416 & 30467841 & 14745649 & 15722192 & 9781907 & 5940285 \\
\hline From 15 to 24 years & 8923072 & 2980732 & 5942340 & 2266845 & 3675495 & 2500062 & 1175433 \\
\hline From 25 to 44 & 25440231 & 12465637 & 12974594 & 6340715 & 6633879 & 4473857 & 2160022 \\
\hline From 45 to 64 & 16519231 & 7226223 & 9293008 & 5001772 & 4291236 & 2419328 & 1871908 \\
\hline 65 years on & 2851894 & 624844 & 2227050 & 1122131 & 1104919 & 376353 & 728566 \\
\hline Not specified & 50829 & 19980 & 30849 & 14186 & 16663 & 12307 & 4356 \\
\hline 1.2 Educational attainment & 53785257 & 23317416 & 30467841 & 14745649 & 15722192 & 9781907 & 5940285 \\
\hline Incomplete grammar school & 5807918 & 720227 & 5087691 & 2195824 & 2891867 & 867283 & 2024584 \\
\hline Grammar school completed & 9336003 & 2088300 & 7247703 & 3625752 & 3621951 & 1846288 & 1775663 \\
\hline Junior high school & 18352232 & 7407905 & 10944327 & 5683723 & 5260604 & 3669375 & 1591229 \\
\hline High school and college & 20238184 & 13075203 & 7162981 & 3231647 & 3931334 & 3385322 & 546012 \\
\hline Not specified & 50920 & 25781 & 25139 & 8703 & 16436 & 13639 & 2797 \\
\hline 1.3 Status in employment & 53785257 & 23317416 & 30467841 & 14745649 & 15722192 & 9781907 & 5940285 \\
\hline Paid dependent workers & 36827208 & 20192753 & 16634455 & 4850865 & 11783590 & 9213894 & 2569696 \\
\hline Salary paid & 34697486 & 19984387 & 14713099 & 4075538 & 10637561 & 8255584 & 2381977 \\
\hline Non-salary paid modalities & 2129722 & 208366 & 1921356 & 775327 & 1146029 & 958310 & 187719 \\
\hline Employers & 2567512 & 1527077 & 1040435 & 1040435 & - & - & - \\
\hline Own-account workers & 12014579 & 1597586 & 10416993 & 7874667 & 2542326 & - & 2542326 \\
\hline Auxiliary non-paid workers & 2375958 & - & 2375958 & 979682 & 1396276 & 568013 & 828263 \\
\hline Not specified & - & - & - & - & - & - & - \\
\hline 1.4 Industry & 53785257 & 23317416 & 30467841 & 14745649 & 15722192 & 9781907 & 5940285 \\
\hline Primary activities & 6717753 & 777468 & 5940285 & - & 5940285 & - & 5940285 \\
\hline Agriculture, fishing and husbandry & 6717753 & 777468 & 5940285 & - & 5940285 & - & 5940285 \\
\hline Secondary & 13786824 & 6874072 & 6912752 & 5362727 & 1550025 & 1550025 & - \\
\hline Mining and electricity & 417200 & 370866 & 46334 & 18473 & 27861 & 27861 & - \\
\hline Manufacturing & 8903071 & 5495395 & 3407676 & 2208470 & 1199206 & 1199206 & - \\
\hline Construction & 4466553 & 1007811 & 3458742 & 3135784 & 322958 & 322958 & - \\
\hline Tertiary & 32960001 & 15624809 & 17335192 & 9379200 & 7955992 & 7955992 & - \\
\hline Trade & 10109798 & 4116344 & 5993454 & 4185683 & 1807771 & 1807771 & - \\
\hline $\begin{array}{l}\text { Hotels, restaurants and food services } \\
\text { stalls }\end{array}$ & 4018289 & 1197099 & 2821190 & 1967905 & 853285 & 853285 & - \\
\hline Transport and communications & 2799865 & 1349381 & 1450484 & 1028531 & 421953 & 421953 & - \\
\hline Financial and professional services & 3844426 & 2612293 & 1232133 & 547237 & 684896 & 684896 & - \\
\hline Social services & 4425435 & 3550083 & 875352 & 150035 & 725317 & 725317 & - \\
\hline Other services & 5525234 & 985628 & 4539606 & 1499809 & 3039797 & 3039797 & - \\
\hline $\begin{array}{l}\text { Government administrations and } \\
\text { international offices }\end{array}$ & 2236954 & 1813981 & 422973 & - & 422973 & 422973 & - \\
\hline Not specified & 320679 & 41067 & 279612 & 3722 & 275890 & 275890 & - \\
\hline
\end{tabular}

Source: INEGI, Encuesta Nacional de Ocupación y Empleo. 


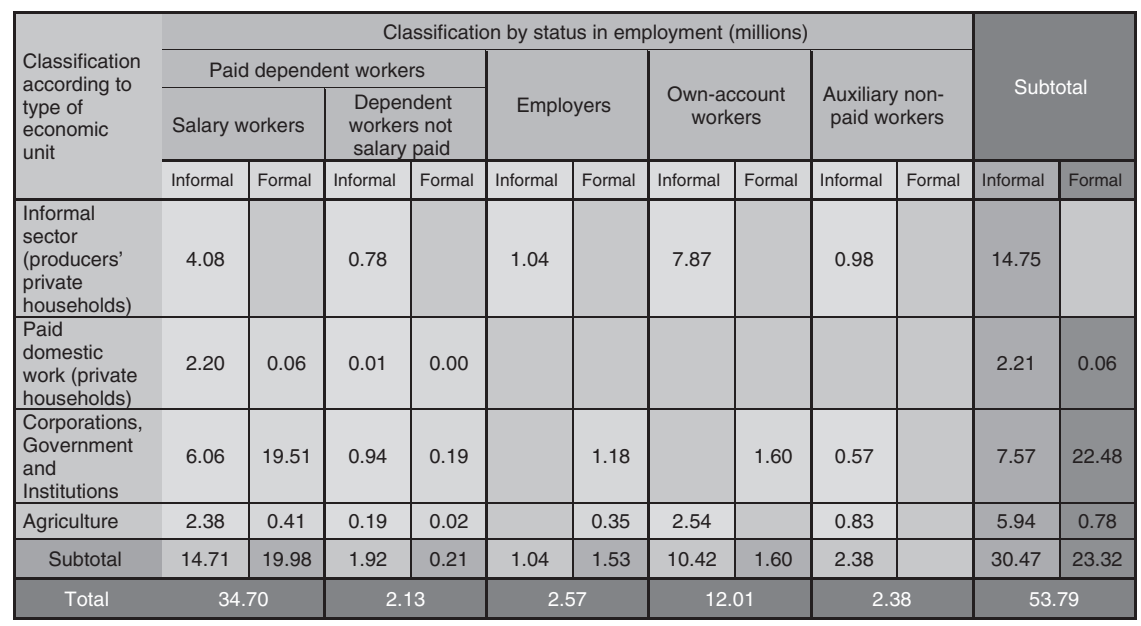

Figure 5.1 The formal/informal labour matrix.

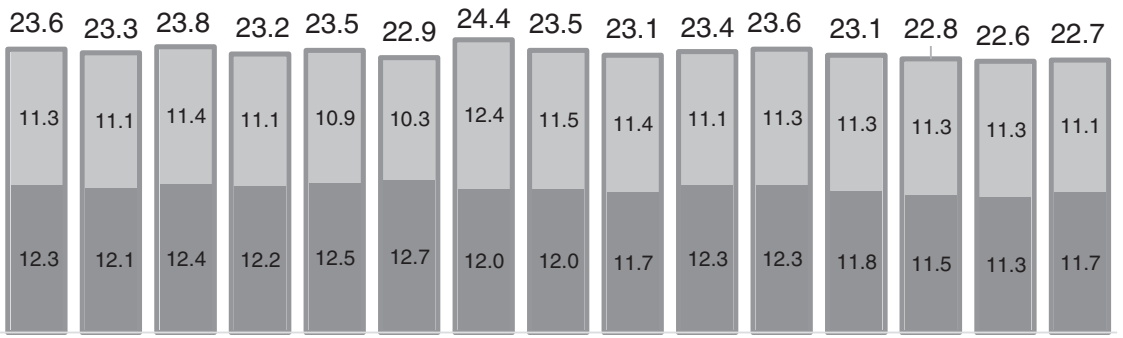

200320042005200620072008200920102011201220132014201520162017

-Outside the Informal Sector $\backsim$ Informal sector alnformal economy

Figure 5.2 Contribution of Informal Economy (Total, Inside and Outside Informal Sector) to GDP.

informal sector. The contribution of the informal sector has been somewhat lower than that of informal employment outside the informal sector. The contribution of informal employment outside the informal sector to total GDP has oscillated mostly between 12.7 and 11.3 per cent.

It is clear that informality is, above all, a structural feature of Mexico's labour market; as such, sudden fluctuations in its share on total employment cannot be expected. However, as a consequence of the global crises in 2008 there was a shift towards a higher level of informal employment than before, as observed between 2009 and 2012. Actually, in the second decade of this century, the GDP growth rate in Mexico has not regained significantly, averaging a rather mediocre 2.5 per cent between 2012 and 2017. However, a string of reforms had an impact in curbing the post-crisis increase in informal employment. Labour 
reform in 2012 that recognised diverse short-time/casual non-standard modalities of labour engagements as legal (and thus entitled to basic social protection as workers) had an important impact. Then, in 2013, the federal government launched an initiative to commit governments down to a state level to register and regularise all supervised workers, including those not previously recognised as such. Next, in 2014, a fiscal reform was launched to give fiscal amnesty to economic units not so far registered before the income tax collector authority (SAT, the Mexican equivalent of the US Internal Revenue Service); specific provisions were added in 2015 regarding micro-scale economic activities, extending the fiscal amnesty years in exchange for registration. All these reforms contributed to a decrease in informal employment both within and outside the informal sector to the lowest levels in years and this in a context of slow economic growth. It is worth mentioning that these reforms were a response to the statistics on informal employment that INEGI placed at the core of the public conversation with regard to the situation of both the labour force and the labour market in Mexico.

\section{Future challenges}

This chapter has shown that the concept of informal employment, and one of its components, the informal sector, are key indicators of the Mexican economy. For these indicators to continue to provide accurate and comprehensive information on the economy, changes will need to be made in their measurement and tabulation to reflect changes in the economy and in statistical standards. For instance, the 19th ICLS and its adoption of the new framework on work statistics classify subsistence production as work, however, not necessarily as employment (ILO 2013c). Moreover the 20th ICLS and the resolution concerning statistics on work relationships identify a new status category, namely dependent contractors, who are workers and formally independent, however, they are operating under the terms set by a third entity which directly benefits from the dependent contractor performance: a labour insertion favoured by the platform/ gig economy (ILO 2018b) and not contemplated before. The identification of these workers will also require changes in both data collection and classification as this group is not specifically covered in the informal employment framework based on the previous classification of status in employment, ICSE-93 (see Figure 5.1). Doing so will create a tension between ways of understanding informality that are based on legal (de jure) criteria and those based on other (de facto) criteria. This is because categories such as dependent contractors can be registered as operators of one-person business (seemingly formal enterprise) while they are dependent and labour under vulnerable or disadvantaged employment arrangements. In particular, they are not entitled to unemployment benefits in most countries, nor to paid sick leave, so, like informal workers, the full burden of economic risk and contingency is on them. 


\section{Rodrigo Negrete}

\section{Notes}

1 According to the international statistical standards adopted by the 15th ICLS, the informal sector consists of a subset of unincorporated enterprises (i.e., not constituted as separate legal entities independent of their owners) that also are not registered with a national government authority. In contrast to the focus on the production unit in the concept of the informal sector, the 17th ICLS guidelines identify a broader concept of informal employment in which the job or worker is the unit of observation. Informal employment refers to an employment relationship that is not, in law or in practice, subject to national labour legislation, income taxation, social protection or entitlement to certain employment benefits. For the full definitions see ILO, Report of the Fifteenth International Conference of Labour Statisticians (Geneva: ILO, 19-28 January 1993) and ILO, Report of the Seventeenth International Conference of Labour Statisticians (Geneva: ILO, 24 November-3 December 2003).

2 For a full description of the survey and the measurement of informal employment, see ILO (2013a).

3 The 19th ICLS does not consider non-paid apprentices as employed. Also, all of the Mexican data produced so far pre-dates the 19 ICLS framework, so also includes the whole of subsistence agriculture (see Future Challenges section). 